\title{
O DEUS "CRISTÃO" DE HEGEL; A ESTRUTURA DAS PRELEÇÕES SOBRE FILOSOFIA DA RELIGIÃO E A REAÇÃO A ELAS
}

\author{
Humberto Schubert Coelho ${ }^{1}$
}

\begin{abstract}
Se diz, assim, que Deus é um ser vivo, eterno, sumamente bom, de maneira que a vida e a duração contínuas e eternas pertencem a Deus; pois isto é Deus.

Aristóteles, Metafisica. (XII, 7, 1072b 29$31)$.
\end{abstract}

\begin{abstract}
RESUMO: Não há dúvidas de que o conceito hegeliano de Deus é peculiar e único, justificando interpretações contraditórias a respeito da relação do filósofo com $o$ cristianismo. Para melhor compreendê-lo, é preciso situar o papel do conceito de Deus em relação aos conceitos de religião e ao conceito de cristianismo, que juntos formam o quadro metafísico e historicista de imanência e revelação do Espírito. A negação da ideia de imortalidade da consciência individual, contudo, fez com que a defesa hegeliana de conceitos fortes de Deus e de cristianismo não fosse vista como suficiente para isentá-lo de acusações de ateísmo e panteísmo. Ao final deste trabalho, portanto, apresentaremos uma dessas críticas a respeito da recepção do pensamento hegeliano pela filosofia e teologia cristãs.
\end{abstract}

Palavras-chave: Deus, Espírito, Cristianismo, Panteísmo, Imortalidade.

Abstract: There is no doubt that the Hegelian concept of God is a unique one, justifying contradictory interpretations about the philosopher's relation to Christianity. In order to understand it, one must situate the role of this concept of God in relation with the concepts of religion and Christianity, which together form the metaphysical and historicist structure of immanence and revelation of Spirit. The rejection of the idea of immortality of individual consciousness, however, made him target of charges of atheism and pantheism, despite the fierce Hegelian defense of God and Christianity. Therefore, in the end of this paper I will present one of these criticisms on the reception of Hegelian thought by Christian philosophy and theology.

Keywords: God, Spirit, Christianity, Pantheism, Immortality.

\footnotetext{
${ }^{11}$ Professor do programa de pós-graduação em filosofia, departamento de filosofia, UFJF.
} 


\section{O lugar conceitual de Deus:}

Neste trabalho tomei a decisão de deliberadamente afastar parte da obscuridade da terminologia hegeliana e apresentar com a máxima clareza a ideia de Deus contida nas Preleções sobre Filosofia da Religião (PFR). O problema de Deus, que se patenteia como basilar no sistema hegeliano, encontra nas PFR um alto grau de transparência, permitindo traduzir em linguagem filosófica a essência do conjunto simbólico da doutrina cristã, o que, ao mesmo tempo, atesta sua excelência e a capacidade superior da filosofia em subsumir a seu modo todos os demais elementos do pensamento.

Até os dias de hoje, as razões para a defesa filosófica da crença em Deus se relacionam fundamentalmente com dois problemas: não é possível justificar a relação, muito menos a causação de propriedades mentais a partir de propriedades materiais, e não é possível justificar a epistemologia a partir de um ponto de partida externo à mente humana e ao ato de filosofar (PLANTINGA; TOOLEY, 2014). ${ }^{2}$

O papel da mente e dos atributos aparentemente mentais da realidade concorre para a conclusão já insinuada na filosofia clássica grega de que a realidade última deve

\footnotetext{
${ }^{2}$ Esses argumentos são expostos por Alvin Plantinga segundo uma formatação consentânea com discussões presentes, mas podemos converter a segunda proposição no antigo problema gerado pelo determinismo, que é o de não podermos saber se nossas crenças sobre o mundo possuem alguma validade judicativa ou são inteiramente condicionadas, escapando de nosso controle, caso em que não faria mais sentido dizer que estamos engajados em uma investigação verdadeira, ou que nossas divergências sobre ela possam ter relação com argumentos. Embora ambas as proposições sejam objetáveis, nenhuma delas foi invalidada até o momento. A primeira não foi invalidada porque não apenas é conceitualmente inviável explicar propriedades mentais usando exclusivamente as propriedades físico-químicas e as medições estatísticas usuais na descrição do mundo físico, mas também porque as tentativas correntes e muito sofisticadas de explicação de funções mentais básicas a partir das neurociências contêm sempre gaps constrangedores. A segunda, talvez mais bem contra-atacada atualmente, resta de pé porque é mais fácil justificar a correspondência entre nossas mentes e a realidade física se ambas forem propositalmente feitas para essa correspondência, já que, pela assumida disparidade mente-corpo anterior, é necessário (e difícil) justificála. Podemos, então, optar por um realismo garantido por Deus ou um transcendentalismo garantido por Deus, não conseguindo de outro modo justificar nossas crenças sobre o mundo a partir da ideia de que é o mundo que determina essas crenças. Por fim, Plantinga também levanta um terceiro argumento com respeito à noção de função apropriada. Segundo o naturalismo, jamais poderíamos julgar como apropriada/inapropriada qualquer função. Viver ou morrer, funcionar ou não, seriam juízos da folk psychology estreitamente ligados ao desígnio, não aplicáveis ao mundo natural, pois, para este, o que acontece é o que deve acontecer, sendo irracional atribuir valoração funcional a qualquer processo (PLANTINGA; TOOLEY, 2014, p. 32). Embora esse terceiro argumento também tenha muito a ver com o desenvolvimento do conceito de Deus no idealismo, ele passa mais ao largo do recorte aqui apresentado.
} 
ter natureza mental. ${ }^{3}$ Mas, como já sabido desde o nascimento da filosofia, a busca por um fundamento absoluto qualificável como arkhé definitiva exige necessariamente que

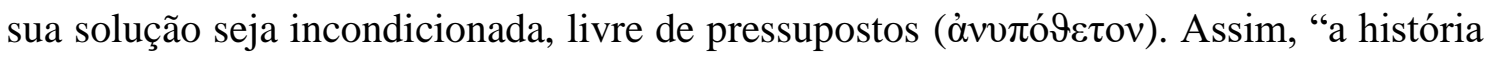
da filosofia é a história do descobrimento do pensamento sobre o absoluto, o qual é seu objeto. É por isso que se pode dizer que Sócrates, por exemplo, descobriu a definição ${ }^{4}$ de propósito, elemento que seria elaborado e mais bem conhecido por Platão e, especialmente, Aristóteles.” (HEGEL, 1970, VIII, 22). Destarte, Hegel concebe o papel da filosofia como intimamente ligado a uma visão científica de Deus. ${ }^{5}$

Hegel não tem problemas em admitir, por exemplo, a aleatoriedade no mundo, desde que essa aleatoriedade não significa ausência de contingência e sentido intrínsecos, mas tão somente uma dificuldade em acomodar certos fatos empíricos ao esquema de mundo que uma pessoa ou comunidade montam para si. Se um acidente natural atinge uma cidade, não se deve cogitar de haver um plano de Deus imbuído de motivação moral e existencial exata para cada vítima e cada sobrevivente, mas, ao invés disso, a população deve antes aceitar racionalmente que acidentes fazem parte da vida e da ordem natural, direcionando seu esforço moral para a reconstrução da cidade, que é a parte que lhe cabe. Nas palavras de Henrich, é belo e admirável tentar enquadrar cada mínima ação particular em uma ordem e propósito, mas essa tentativa não encontra sentido além de nossa concepção finita do que deveria ser o plano, de modo que é mais saudável investirmos

\footnotetext{
3 "É claro, o voluntarista se agita pela reflexão de que condicionar Deus à lógica ou à moralidade significa limitá-lo a algo externo a ele, furtando-lhe, assim, a absoluta onipotência. A única resposta a esta objeção é a de que verdades lógicas, lei moral, e talvez todas as eide e as leis que regem o ser não são antecedente a Deus, mas são elas mesmas Deus. Isso parece, no entanto, transformar Deus em um conjunto de verdades absolutas. Não é possível enxergar como ele possa ser ainda algo como uma pessoa. Como vimos antes, na tradição platônica o ser verdadeiro era concebido segundo um padrão de ideias. [...] Eu concedi que Platão fosse incapaz de capturar as formas específicas do ser de infinita subjetividade, e não deveria ser surpresa que ele tinha dificuldade em atribuir uma subjetividade de amplo espectro a Deus, mesmo que ele tenha se dedicado à questão no Sofista. Mas qualquer um que reconheça que a mentalidade é uma forma irredutível do ser, e que ela é axiologicamente superior ao ser não-mental, não pode evitar interpretar Deus como mente." (HÖSLE, 2013, 9)

${ }^{4}$ Aqui, Bestimmung poderia ter tradução mais literal como 'determinação', mas a sentença soaria menos clara em português.

${ }^{5}$ Sobre isso, Peter Hodgson observa em Hegel and Christian Theology: "Quando se remove os parênteses da Fenomenologia, fica claro, diz O'Reagan, que o sujeito ultimo do devir não é o ser humano individual ou a sociedade, mas sim Deus, o transcendental significado - ou, nos termos de Hegel, nem espírito subjetivo nem espírito subjetivo, e sim espírito absoluto." (HODGSON, 2005, 17)
} 
nosso potencial intelectivo na compreensão da naturalidade dos acidentes e na reação a eles, pois tais ocorrências são "inessenciais" à vida do homem, enquanto suas obras espirituais não (HENRICH, 1967, 173).

Admitindo as ideias de propósito, liberdade e razão como imanentes e generalizadas, Hegel não chega, contudo, a humanizar o mundo a ponto de ignorar o papel da contingência, do determinismo e do acidente, e é a conjunção desses princípios em uma forma orgânica e complexa de acomodação de suas distintas vigências que torna tão inamistoso o seu pensamento.

Para compreender a ideia de Deus, portanto, temos de retornar às muitas referências conceituais espalhadas pela obra hegeliana em suas diferentes tentativas sistematizadoras, trazendo à consciência a relevância do conceito, da ideia, da razão, da unidade, da vida, do absoluto, para citar alguns elementos imprescindíveis ao processo total vislumbrado e construído pelo autor. Em termos, o que Hegel quer significar com seu uso peculiar das palavras 'Deus' e 'Absoluto' é que devemos nos perguntar em que sentido podemos seriamente dizer que "em Deus somos, nos movemos e temos nosso ser”; ou que Deus é tudo, está aqui (HEGEL, 1970, VIII, §13); ou que o pensamento se descobre como pensamento do pensamento na figura de Deus. A necessidade de começar pelo inverídico (ser), para chegar à verdade (Deus), é patente na forma do desenvolvimento do espírito absoluto. Esse processo "só é por nós conhecido, se reconhecemos o mundo criado, a natureza e o espírito finito como inverídicos em comparação com Deus" (HEGEL, 1970, VIII, §83). Logo, o jogo entre ser, essência e absoluto é mais complexo do que o monismo hegeliano costuma soar nas exposições reducionistas de seus adversários. A essência só se reifica como idêntica a si mesmo porque se vê refletida em um outro. Por isso, ao contrário do ser, a essência é determinada em contraposição (pela diferença) (HEGEL, 1970, VIII, §142). Substancialidade é a propriedade de subsistir em si mesmo, o que em parte é uma ilusão, visto que todo particular é em função de um geral, mas tem validade na medida em que se pode perseverar no seu ser próprio dentro do movimento da totalidade. Essa subsistência, contudo, tem de ser autorreferencial em face do diferente. Da reciprocidade entre duas substâncias decorre a causalidade, que é mutua efetividade. Ora, a propriedade de ser 
necessariamente que pode ser vislumbrada como causalidade é desdobrada da autossubsistência das substâncias, e então, da liberdade.

Esta forma exótica de solução da adequatio rei intelectus traz traços distintivos do neoplatonismo. ${ }^{6}$ Por isso toda substância extrai sua força do conceito, que é a pura autodeterminação livre (HEGEL, 1970, VIII). Na raiz, como no manifestar de cada indivíduo, está o espírito, não enquanto abstração ou pura intelectualidade, como ele foi concebido na Grécia, e sim como espírito vivo e criador, fomentando a especificação de cada particular no quadro da totalidade (HEGEL, 1970, X, §384).

As Preleções sobre Filosofia da Religião colocam ênfase sobre a organicidade entre ser e saber, "Porque a determinação do puro pensar pertence ao determinar da essência...” (HEGEL, 1970, XVII, 17), tendo em vista que o que é dito de Deus é dito sobre a essência do ser e não sobre conceitos abstratos. "Já para os neopitagóricos e os neoplatônicos, os quais ainda permaneciam no mundo pagão, os deuses do povo não eram deuses de fantasia, tendo se tornado deuses do pensamento.” (HEGEL, 1970, XVI, 40) Contudo, a filosofia trata o supremo como absoluto e como ideia, a religião trata-o não apenas como pensado, mas como manifesto. Por isso, a filosofia da religião tem de assumir que a religião enxerga Deus como manifesto, enxerga o ser de Deus, sem que, por outro lado, a ela possa ser entendida como superior à filosofia, já que esta leva à total consciência o que aquela tão somente representa (EBERT, 1996, 95-96).

Hoje é ponto comum que o sistema de Hegel implica em panenteísmo. ${ }^{7}$ A ideia que ele fazia do panteísmo não admitia um reducionismo das coisas a Deus, ou, como comumente se diz, uma panteísmo em que o indivíduo fosse reduzido a nada, absorvido no Espírito de forma desumanizante, e isso por duas razões: porque Deus não é simplesmente tudo o que existe, mas aquilo que, em tudo o que existe, faz com que as

\footnotetext{
${ }^{6}$ Lembrando, primeiramente, que o neoplatonismo inclui uma séria absorção da contribuição de Aristóteles à definição estrutural do ser. Conforme Jens Halfwassen, pensadores como Eusébio de Cesaréia, Plotino, Proclo, Jâmblico e Fílon de Alexandria têm grande importância nesse comenos, transmitindo a Hegel a convicção de que os seres pensantes, finitos ou infinito, possuem em si unidade e inteireza por força mesmo de sua natureza pensante, enquanto pessoas, e isso torna pensável a comunhão íntima entre dois seres pensantes, e de todos com aquele que é infinito. (HALFWASSEN, 2005, 71-82)

${ }^{7}$ A título de exemplo: (HODGSON, 2005, 106), (COOPER, 2006, 91; 107-109)
} 
coisas sejam o que são, ${ }^{8}$ e porque ele fez da substância sujeito, não havendo mais sentido em ver na totalidade espiritual uma desumanização semelhante à que se pode ver em um panteísmo ou um monismo onde a totalidade não se identifique com o humano ou tome por ilusória uma parte essencial do humano. "O Deus de Hegel não é o todo alheio, mas o todo dos todos, o universal que englobe toda a alteridade e toda a diferença." (HODGSON, 2005, 264)

Similarmente ao que se observa desde a Fenomenologia do Espírito, a totalidade hegeliana é a unidade imanente dos particulares. A natureza engloba tanto a vida quanto a morte, e não a vida apesar da morte, mas uma e outra intensificando-se mutuamente em mesmo grau. O viver é marcado pela morte, ao passo que os seres inanimados desconhecem a morte, são imortais, mas também não vivos. Assim, a morte não aparece na natureza como maldição, e sim como determinante da vida. A natureza tanto dá quanto tira a vida, e o seu aspecto trágico é visto com serenidade pelo filósofo, pois ele não espera a superação do diferente, do negativo, do finito e, portanto, da morte. Parte do ataque a Schelling tem sua razão de ser na impressão de Hegel de que a filosofia da identidade daquele não considerava com suficiente gravidade a força da negatividade (HENRICH, 2003). O Espírito é infinito justamente em seu finitizar (HEGEL, 1970, X, §386), na forma como a multidão dos particulares estão intimamente tramados numa tessitura comum. Por isso, o tom schellinguiano de uma hipostasiação do particular e da diferença a partir de uma identidade só ela verdadeira soa como fracasso do projeto sistemático aos olhos de Hegel. Os resultados desse distanciamento da filosofia de Schelling deixam entender, para alguns, que o papel de Deus na filosofia de Hegel seria menor, quando, de fato, todo o projeto hegeliano parece querer elevar a função de Deus à de substância concreta, oposta à visão que ele entendia como abstrata, de Schelling.

Conceito hegeliano de religião:

\footnotetext{
${ }^{8}$ Com isso, Hegel se afasta do que entende por cristianismo ortodoxo, o qual teria permanecido preservado da crítica de Kant, e abraça uma reestruturação "agressiva" dos conceitos de Deus, sua relação com o mundo e com o homem (MEIST, 1997, 64-66), mas, ao mesmo tempo, não permite que essa guinada o converta em uma espécie de contestador das verdades seminais contidas no cristianismo.
} 
A reconstrução da prova ontológica moderna remonta a Descartes, passando por Leibniz, até Baumgarten e Bering, terminando no argumento deste último de que 99 táleres reais valem mais do que 100 táleres fictícios, de modo que a concepção de 99 táleres reais é incomparavelmente mais valiosa que a de 100 táleres imaginários (HENRICH, 1960). Do ponto de vista do velho argumento do grau de realidade, os táleres reais seriam apenas um pouco mais reais do que os possíveis. Mas ao retirarmos um táler ficamos com um grupo de 100 possíveis, de um lado, e 99 reais, de outro, sendo que a sua realidade lhe dá uma pequena vantagem, e a diminuição de um táler retiraria esta vantagem. Na consciência de nenhuma pessoa real, contudo, os 100 táleres possíveis terão um valor comparável ao dos 99 reais (ou 50,10, um único táler real), pois a diferença de realidade entre os táleres possíveis e os reais não é progressiva ou gradual, mas binária: existente ou não existente (HENRICH, 1960, 120).

Na crítica de Kant ao argumento ontológico, contudo, observa-se que não há como distinguir absolutamente nenhuma diferença de valor entre cem táleres reais e cem táleres pensados. Isto porque existir ou ser não constitui ato predicativo (HENRICH, 1960, 139) Adicionalmente, Kant mostra a irreligiosidade dessa tentativa de salvaguardar a existência de Deus, já que a prova não eleva, e sim reduz Deus à categoria dos existentes, do mundo. Kant quer ressaltar, sobretudo, que a noção de existente, validada pela experiência, não cabe a Deus, que é puro espírito, e deve ser contemplado pela razão como ideia.

Hegel considerava os argumentos de Kant uma falha fatal na compreensão da essência da religião, uma vez que Kant entendia por religião um conjunto de afirmações metafísicas desvinculadas da experiência e, por isso, com mero valor hipotéticoregulativo na orientação da vida moral. Para Hegel, a incapacidade de Kant em perceber o conteúdo da religião levou este a uma admissão senso-comum de sua invalidade objetiva. Hegel, ao contrário, afirmava que a religião não apenas é concreta, envolvendo todo um leque de experiências da consciência em relação a Deus, mas a própria relação entre Deus e o homem seria totalmente vazia se Deus fosse apenas uma ideia humana, uma expressão subjetiva (WILLIAMS, 2017, 56-58). Ao invés disso, a fenomenologia da vida religiosa testifica que o relacionamento do homem com Deus sempre foi um 
relacionamento de mão dupla, onde o homem se sente muitas vezes receptor passivo de uma manifestação do divino, ao invés de apenas produtor de ideias e intenções religiosas.

Em outras palavras, a estrutura lógica da consciência não permite que a subjetividade finita produza uma subjetividade infinita, resultando em que a religião seja por si só um fato, e um fato imprescindível na dinâmica do espírito, pois atesta de modo radical a inclusão da subjetividade finita na economia de uma subjetividade infinita, ou seja, que tudo está em Deus.

Trata-se, certamente, de um fato sobre a constituição do espírito, da impossibilidade de elevação do espírito fragmentado à completa reconstituição orgânica do Todo. Uma vez que a subjetividade evoca em sua constituição, por sua própria definição, a finitude e a particularização na qualidade de uma perspectiva de primeira pessoa e também por seu lastreamento empírico, o horizonte de sentido do ser, infinito, adquire um caráter transcendente, necessariamente e por razão dessa mesma constituição (DIERKEN, 2005). Ora, a busca da razão por um sentido geral do mundo acaba por se identificar como reencontro do saber universal que permite ao saber finito a pergunta sobre sua origem genética. Ser racional, assim, é conter em si implicitamente a inteligência absoluta.

Com isso, a potência da razão em elevar-se ao Todo é ela mesma o fato religioso, de modo que o fato religioso é "visto" na religião, mas é produzido pela razão mesma. E isso o leva a afirmar: "Mas, de fato, não existe ser humano tão corrompido, tão perdido e tão mau, e não devemos nem mesmo considerar alguém tão desgraçado a ponto de nele não haver absolutamente nada da religião" (HEGEL, 1970, XVI, 15).

Hegel não discorda de Kant quanto a haver uma substancial diferença entre conceito e realidade, mas ele observa que Kant nivela o conceito de Deus como outro qualquer, ao passo que, para ele, o conceito de Deus é de outra natureza modal, pois é o conceito do absoluto, não de um ente representado. Portanto, o conceito de Deus é o único que tem de envolver necessariamente sua veracidade (WILLIAMS, 2017, 117). De certa forma, é como se o conceito de Deus não pudesse ser submetido às regras que regem pensamentos contingentes, pois ele é o pensamento de que o pensamento encontra justificação no ser, tendo mais a ver com o problema platônico da pensabilidade do real. 
A filosofia e a religião têm, pois, em comum o conteúdo, que é a verdade do espírito. A religião é como que uma descoberta do espírito acerca de sua origem, uma descoberta que também fala sobre esta origem, o Absoluto. Sendo tomada de consciência acerca de si mesmo, a religião é racional, e não pode deixar de sê-lo em seu feitio mais puro, mas certamente não é racional por ser calculada, derivada de certos princípios $a$ priori, senão por ser ela mesma uma razão reveladora da verdade. Nas palavras de Hegel: “A religião é um produto do espírito de Deus, não uma invenção do homem, mas obra da ação e anunciação divina nele. A expressão de que Deus rege o mundo como sua razão não teria sentido se não assumíssemos que ele também se relaciona com a religião, e que o espírito divino atua sobre a sua forma e definição" (HEGEL, 1970, XVI, 40).

Por esta natureza, a religião conserva os princípios mais elevados da humanidade, operando na desprestidigitação que o espírito exerce sobre a ilusão do mundo, quando desta é consciente. A filosofia apoia-se sobre as mesmas bases, na medida em que seu fundamento é o Lógos universal em si e para si. Seguindo o trabalho dos espinosanos alemães, Hegel solapa a distância transcendental entre sujeito e natureza e recupera o sentido do Lógos, a razão universal da qual o homem é herdeiro direto. Por conseguinte, ver na religião apenas uma superstição, ou segui-la fanaticamente como ordenamento heterônomo patenteiam ambos o desconhecimento de si. É só porque o espírito está alienado, não está de posse de si mesmo na realização de sua própria vocação, que ele pode crer numa religião sem o distanciamento do mundo, ou crer num mundo sem a conciliação da religião. Por isso, a religião não deve permanecer desacompanhada de sua consciência fiscalizadora, a filosofia.

O objeto da religião, como da filosofia, é a eterna verdade em sua objetividade; Deus, e nada além de Deus e da explicação de Deus. A filosofia não é sabedoria mundana, e sim conhecimento do não mundano, não o conhecimento da massa exterior, do ser empírico e da vida, mas o conhecimento daquilo que é eterno, do que é Deus e do que flui de Sua natureza. Essa natureza tem de se revelar e se desenvolver. A filosofia, então, só se explicita quando explicita junto consigo a religião, e ao explicitar-se explicita, de todo modo, a religião (HEGEL, 1970, XVI, 28). 
No entanto, não se deve inferir, por isso, que a visão de Hegel sobre a religião fosse tão ortodoxa quanto algumas passagens possam sugerir ao leitor incauto. O conjunto da obra evidencia muito claramente uma visão secularizada em bastante conformidade com a tradição de crítica teológica de Espinosa, Lessing e Kant, sendo seguramente mais radical que os dois últimos. Como observou Karl Barth, há boas razões para um pensador tão grande e que tratou a religião tão ostensivamente não tenha se tornado um símbolo, uma espécie de "Tomás de Aquino luterano" (DE NYS, 2009, 1).

Na Enciclopédia das Ciências Filosóficas, por exemplo, ele compara os entusiastas do vidente de Prevost com incautos que dão curso à obra do diabo e renegam a sobriedade da moral de Cristo (HEGEL, 1970, XVII, 34), e todo o texto das PFR apresenta duras críticas às noções de milagres e supernaturalismos, incluindo-se entre os elementos criticados a imortalidade da alma e a ressurreição.

Assim, o tom apologético em favor da religião precisa ser compreendido como também uma defesa da concepção hegeliana de religião, a qual, com razão, é quase indissociável da filosofia. A preferência de Hegel por autores cristãos controversos, como Eckhart e Böhme (KOLB, 1992), sugere que ele realmente não se enquadra em definições tradicionais. Não obstante, esses mesmos autores muito comumente sejam apontados como cristãos exemplares, apesar de doutrinariamente controversos, o que também sugere que Hegel não tende para uma forma extremamente heterodoxa de cristianismo.

Religião é "aquela região de nossa consciência onde todos os enigmas são resolvidos, todas as contradições dos mais profundos pensamentos são devassadas, todas as dores do sentimento são silenciadas, é a região da eterna verdade, da eterna serenidade, da eterna paz. Através dela o ser humano se faz humano, ela é o pensamento em absoluto, o pensamento concreto... Tudo aquilo que possui valor e merece o respeito dos homens, aquilo em que buscam sua felicidade, sua glória e seu orgulho, encontra seu centro de equilíbrio na religião, no pensamento, na consciência e no sentimento de Deus. Deus é, assim, o princípio e o fim de tudo; da mesma forma como tudo provém deste ponto, tudo retorna a ele; e é por isso que ele é o meio que a tudo vivifica, apraz, e espiritualiza todas as formas, sustentando-as em sua existência. Na religião, o homem coloca- 
se em relação com esse meio no qual todas as suas demais relações se arranjam, e, com isso, ele se eleva ao mais alto grau de consciência e à região em que, livre de relações com o alheio, encontra o puro contentamento, o incondicionado, a liberdade e o propósito final para si mesmo. (HEGEL, 1970, XVI, 11)

Como resultado, temos um conceito de religião que a purifica do aspecto idólatra da figura de Jesus e das superstições e traços mitológicos que a acompanham desde os séculos quarto e quinto aproximadamente.

Para Hegel, a tarefa de evitar os elementos escatológicos da imortalidade e da ressurreição factual de Jesus, a qual não tem outro papel que o de comprovar a imortalidade, e a consequência metafísica de um aumento incomensurável da individualidade estendida a um plano ontológico marcado pela eternidade, passava por uma forte valorização dos monismos místicos cristãos, ao estilo de Eckhart e Angelus Silesius (O'REAGAN, 1992,118). Eles seriam sua ponte para a conciliação entre o espinozismo que lhe enchia os olhos do espírito rigorosamente totalizante e o cristianismo que ele não podia negar como anunciação de seu próprio projeto metafísico.

De qualquer maneira, a grande contribuição de Hegel para a filosofia da religião inclui, no mínimo, uma profunda extração e destruição tanto dos traços antropocêntricos quanto das versões abstratas do conceito de Deus, liberando-o para a reflexão filosófica mais direta e mais franca. Foi, portanto, parte culminante do processo de resgate do conceito de Deus da exclusividade doutrinal ou dogmática da teologia cristã para o campo da crítica franca. E isso sem recair numa crítica de tal modo obsessiva que eliminasse inteiramente a dimensão religiosa substancial e legítima que caracteriza o conceito de Deus, como ele bem reconheceu, como algo natural e universal na experiência humana.

Basicamente é nisso em que consiste ser um filho de Deus: conservar sua individualidade enquanto filho, e herdar o Universo como sendo originado do Absoluto. Essa herança, enquanto herança do Espírito, é o conhecimento adequado do Universo. Visto por esse ponto de vista, o caráter sui generis de Jesus Cristo pode ser racionalmente compreendido em sua função verdadeira no processo universal. 
Deus, na primeira expressão menos filosófica dos povos primitivos, tem de ser puramente um sujeito. Como sujeito individual ele é identificado como pessoa, mas uma pessoa abstrata, dotada de saber, poder, grandeza e virtudes, mas afastado de nosso ser como um estrangeiro com o qual jamais tivemos contato. Ele nos é estranho enquanto deus. Para que fosse nosso Deus, e o Deus de todos, de tudo, a consciência teve de superar o conceito de estranhamento, bem como as noções menos espirituais de imanência, em favor da familiaridade. Por isso Jesus nos revela um Deus Pai, em oposição ao monarca, supremo juiz ou divindade olímpica sem laços diretos com cada ser individual.

Essa preocupação se estende, entre outros elementos, ao conceito de trindade, o qual Hegel reconhece não apenas desenvolvimento por etapas da manifestação do mundo como também enquanto etapas da aparição do espírito à consciência. Para o entendimento da teoria da religião de Hegel, como qualquer outro elemento de seu pensamento, é fundamental compreender que o termo Geist tem, já na Fenomenologia do Espírito, duas conotações complementares. Por um lado, Geist é a mente, e expressa todo o patrimônio de uma subjetividade ativa, mundificada e engajada no jogo intersubjetivo da estrutura social. Por outro lado, Geist é também espírito, em um sentido explicitamente cristão e "correspondente ao terceiro momento da estrutura trinitária de Deus." (SCHLÖSSER, $2015,110)$

De acordo com o conceito filosófico Deus é espírito, concreto; e se indagarmos mais de perto o que seria o espírito, então o conceito fundamental de espírito seria aquele desenvolvido em toda a doutrina religiosa. Brevemente poderíamos dizer que espírito é o seguinte: se manifestar, ser para o espírito. O espírito é para o espírito, e isso não exteriormente e de modo acidental, mas ele só é espírito na medida em que é para o espírito; é nisso em que consiste o conceito de espírito. Ou, para expressá-lo teologicamente, Deus é espírito essencialmente na medida em que ele é em sua comunidade. Foi dito que o mundo, o universo sensível, tinha de ter expectadores e tinha de ser para o espírito, - assim Deus com muito mais força tem de ser para o espírito (HEGEL, 1970, XVI, 52).

Isolado, o elemento em si de Deus equivale a seu estado antes da criação do universo (HEGEL, 1970, XVII, 218), e, como não pode ter havido percepção ou intuição 
de nada outro antes da criação, seu pensamento é uma pura intuição imediata de si, pura atividade pensante. A atividade que se opõe a esta total concretude da verdade infinita é a da abstração de finitude. Da cisão entre o abstrato finito e o concreto infinito surge a esperança de uma reconciliação, reconhecida como o amor. O amor é a minha autoconsciência em um outro ((HEGEL, 1970, XVII, 222), pois os diferentes são unidos sinteticamente no mútuo reconhecimento de que a completude não pode ser individual. Deus enquanto puro Pai não é ainda verdadeiro (HEGEL, 1970, XVII, 223), pelo que cria o Filho desde toda a eternidade para a comunhão com um outro de si. Aqui, enfim, se entende a completude da ideia hegeliana como conciliadora entre finito e infinito, e como expressão maior de uma ipseidade lastreada na diferença. Por isso a verdadeira eticidade, calcada no amor, "é a desistência da personalidade e o alargamento na generalidade, isto é, família, amizade [...] Ao agir bem em relação ao outro, passo a observá-lo como idêntico comigo. Na amizade, desisto de minha personalidade abstrata e a recupero em forma concreta, através do amor." (HEGEL, 1970, XVII, 233) Tal é o atestado de superioridade do conceito cristão de Deus: ser capaz de subsumir em si processos concretos e fundamentais do grande processo da consciência.

Nem teísta-dualista nem panteísta-monista crasso, Hegel ressalta, inclusive, a impossibilidade de estabelecermos valores seguros e permanentes para as definições capitais de subjetividade, espírito ou Deus. ““"Deus é infinito, eu finito”, essas são formas e expressões falsas, ruins, que não são apropriadas à ideia e natureza da questão. O finito não é o existente; de igual maneira, o infinito não é fixo: essas determinações são apenas momentos do processo." (HEGEL, 1970, XVI, 192)

Apesar dos cuidados de Hegel, contudo, seu conceito de Deus foi logo associado ao panteísmo crasso, a um tipo de monismo que ignora e apaga as individualidades. Hegel reage nas PFR negando, não que ele fosse um panteísta dessa lavra, mas que houvesse qualquer religião capaz de defender sinceramente a destruição da individualidade.

Quando Brahma diz: "Eu sou o brilho, o luzir nos metais, o Ganges entre os rios, a vida dos viventes", e assim por diante, o particular é suspendido com isso. Brahma não diz: "Eu sou o metal, os rios, as coisas particulares de cada tipo enquanto tais, como existem imediatamente.” O brilho não é o próprio metal, mas 
a generalidade, a substancialidade que perpassa os particulares, não se trata mais de um $\pi \alpha v[\ldots]$ Com isso já não se está expressando aquilo que originalmente significa panteísmo, se está falando da essência destas coisas particulares (HEGEL, 1970, XVI, 98).

Com isso Hegel faz a defesa de Espinosa junto com a de sua própria visão da religião, denunciando a perseguição de Jacobi e outros pensadores luteranos ortodoxos como má compreensão do panteísmo espinosano. Ao contrário do materialismo por eles vislumbrado, e conforme Schelling já havia observado nas Cartas sobre o dogmatismo e o criticismo, Hegel afirma nas PFR que nada é mais divino do que uma filosofia que permeia tudo com a essência divina, onde o mal e o erro não existem, e tudo é digno de amor e admiração. Esse elogio parecer ser sincero, apesar de ele próprio não nos apresentar um quadro filosófico tão otimista e luminoso, e apesar do fato de que o próprio pensamento espinosano fosse mais estoico do que otimista.

Prova cabal de que esse reducionismo monista não corresponde ao intento de Hegel é a inserção das noções de reconciliação e reconhecimento, já muito complexas desde a juventude de Hegel e a fase da Fenomenologia do Espírito. E também as análises que Hegel faz do animismo e das religiões asiáticas deixam claro que o panteísmo crasso é um estágio intermediário da consciência.

Em sua fase primitiva, como religião natural, a ideia de Deus é tão somente projeção ampliada da mente humana, uma exteriorização das características mais elevadas que o homem encontra dentro de si mesmo. Ele intui que essas características devem ter correspondência com o Todo, mas não executa a transição na forma profunda e completa do pensamento, limitando-se a esboçar um simulacro (HEGEL, 1970, XVI, 267-276).

A consequência desta precariedade reflexiva é que o homem vive sua religiosidade em face do externo, buscando a salvação ou a libertação em algo fora dele, o que Hegel caracteriza como fase mágica da religião. Nela o homem projeta para objetos, danças, comidas e rituais bastante sensuais a sua demanda pelo espiritual, a qual certamente não pode ser assim saciada (HEGEL, 1970, XVI, 301). Em um segundo 
momento, que seria o momento "metafísico", a consciência humana percebe a insuficiência da dimensão material e reconhece que a substância do mundo deve ser independente dela, mas, então, a abstrai como fantasia ou mundo transcendente inteiramente desvinculado da realidade vivida.

Com isso, se vê surgir uma espécie de panteísmo puramente espiritualista, mas de um espiritualismo abstrato, estático, com a consequente negação do mundo físico ora entendido como ilusão. Tal é a religião não apenas dos hindus, mas também de muitos antigos, como alguns pré-socráticos e neoplatônicos. Para essa fase abstrata do espírito Deus é o inteiramente espiritual oposto à nossa natureza finita e diversa, sendo, portanto, oposto ao homem. A bem da verdade, o homem e os demais seres são negações de Deus, que precisam ser canceladas em favor dele (HEGEL, 1970, XVI, 340-348). Os indianos inclusive já esboçavam a ideia da encarnação de Deus, na figura de Krishna. Entretanto, Krishna é uma encarnação apenas nominal de Deus, pois não se efetiva como síntese eficiente entre o homem e o espírito, soando-nos apenas como promessa dessa síntese. ${ }^{9}$ E o que para a religião hindu significa a comunhão com Deus ou o absoluto impessoal é, para nós, "uma submersão e esfumaçamento da consciência no altíssimo, e quem se sustenta nessa abstração e cancelamento do mundo se chama yogue." (HEGEL, 1970, XVI, 361)

Parte do esforço despendido na última versão das PFR objetiva elucidar a positividade da religião e a superioridade do cristianismo naquilo que essencialmente constitui o processo da consciência ligado ao pensamento religioso. Por isso, para

\footnotetext{
${ }^{9}$ É por afirmações como esta que Hegel é considerado como um pensador eurocêntrico ou colonialista, mas, ao menos nesse caso, ele se restringe ao fato de que o conceito por ele criticado (da encarnação de Deus em Krishna) realmente não cumpre o que promete. Podemos, com razão, denunciar essas posições como historicamente condicionadas e enviesadas, mas é filosoficamente consequente não nos determos nessa explicação extrínseca e levarmos a sério o conteúdo do argumento a fim de pensarmos até que ponto ele é válido independentemente do fato de Hegel ser cristão, eurocêntrico ou o algo além disso. No nível conceitual podemos, por exemplo, perguntar se a metafísica hegeliana está certa e se temos realmente de admitir uma organicidade tão total e uma divindade tão imanente quanto quer Hegel, ou se o platonismo, ou as religiões, não poderiam ter acertado mais ao contrapor mais fortemente o espírito à matéria. Criticas com esse viés, portanto, começam por confundir o método e/ou visão histórica com a proposta conceitual que Hegel apresenta para a leitura da religião, a qual, como de costume, é extremamente própria e não pode ser facilmente lida segundo as referências do senso comum (JAESCHKE, 1997).
} 
entender o conceito hegeliano de religião, o que também significa entender o conceito hegeliano de Deus, é preciso entender o cristianismo.

\section{Alguns elementos do processo religioso em sua expressão cristã:}

A riqueza metafórica da religião deixa claro, para Hegel, que a intenção subjacente ao discurso religioso é intensificar a reconciliação metafísico-teológica através de uma dialética forte; para ele: uma dialética do reconhecimento (SCHLÖSSER, 2015, 125126). A crer em Ulrich Schlösser, inúmeros elementos doutrinais e rituais podem facilmente ser acomodados na compreensão hegeliana segundo a dialética do reconhecimento. A apresentação de Jesus como identificado com o Pai, e a expansão de uma possível identidade entre Deus e o homem em geral nas asserções de tipo "vós sois deuses", "vós sois o sal da Terra", e toda a simbologia sacramental da comunhão. A favor dessa perspectiva contam dois argumentos muito fortes: se o homem realmente não pudesse incluir o infinito numa dialética do reconhecimento essas metáforas religiosas não haveriam de ter significado algum, e, em segundo lugar, se a dialética do reconhecimento não tivesse fundo metafísico mais amplo a interação entre duas pessoas poderia ser rebaixada como função secundária e ainda abstrata da autoconsciência, mas isso definitivamente não parece ser o caso, pois a Fenomenologia do Espírito tem nesse momento um de seus processos centrais, e as obras posteriores só intensificam sua importância e generalidade.

Quanto à reconciliação, que nas obras de juventude equaciona a separação através do amor, o último Hegel sustenta tanto quanto no começo a excelência da revelação cristã no processo reconciliador e a atestação de que a reconciliação é o encontro entre filosofia e religião propriamente dito. "Na religião cristã a necessidade dessa conciliação teve de se evidenciar mais do que nas outras religiões" (HEGEL, 1970, XVI, 24). As PFR apresentam uma evolução lógico-conceitual da religião do animismo primitivo, passando pelo panteísmo místico, o legalismo de um Deus monárquico, a beleza pagã que espiritualiza a matéria e a eticidade do paganismo tardio, até sua culminância no conceito reconciliatório do amor cristão e da imagem da unidade das diferenças na divindade de Jesus e na trindade. 
Não por ser a nossa religião, como pressupõem ataques de viés descolonialista, mas por razões puramente lógicas e processuais, o cristianismo é assumido por Hegel como sendo a expressão mais plena daquilo em que consiste todo o mérito do esforço religioso, assim como o seu próprio sistema expressa em estado superior aquilo que a filosofia deve ser essencialmente, o que não diminui a grandeza de outros autores que tangenciaram a verdade, pois que ela é sempre a mesma.

É a religião por excelência porque apresenta maior número de formas e processos representativos do todo. Sem contrariar a acomodação das ocorrências acidentais no mundo - citada acima na observação sobre o acaso - Hegel leva a sério a preocupação religiosa em diagnosticar a presença de Deus nos acontecimentos, bem como nas ações humanas. Aqui também ele destaca a espiritualidade e superioridade filosófica do cristianismo no que tange às observações de Jesus de que o verdadeiro culto é práticoexistencial, encontrando suas máximas expressões na ação moral, na adoração em espírito e verdade de Deus, na fé e no amor.

O culto cristão parte de um estado de total divisão, tragicamente constatada como dolorosa, "visto como mau desde seu próprio lar, o ser humano é em seu íntimo a negativa de si mesmo, e o espírito, retraído sobre si mesmo, encontra-se apartado do infinito, do ser absoluto" (HEGEL, 1970, XVI, 25). Mas, ao lado da chaga, a consciência acaba por encontrar o bálsamo da reconciliação, justamente porque o espírito não se sente tão sinceramente apartado do infinito, vislumbrando sua presença tácita na falta, na incompletude e na carência que o homem sente tão naturalmente. "A razão humana, a consciência de seu ser, é a razão em absoluto, o divino no homem; e o espírito, na medida em que é espírito de Deus, não é um espírito para além das estrelas, para além do mundo, pois que Deus é presente, onipresente e como um espírito em todos os espíritos. Deus é um deus vivente, atuante e operoso" (HEGEL, 1970, XVI, 40).

Ao contrário de uma visão transcendente que faça de Deus um fantasma infinito, não relacionado com a totalidade do real, o homem deve se integrar ao fluxo do mundo e fazer-se perfeito, como perfeito é o vosso Pai que está nos Céus (HEGEL, 1970, XVI, 43). "A religião completa (o cristianismo) é completa porque seu culto é o mais imanente no contesto da religião. $\mathrm{O}$ caráter representativo fica, assim, reduzido ao mínimo, e a 
práxis cúltica se mostra como algo espiritual (obra de Deus também em sentido subjetivo)" (VINCO, 2015, 246).

Ao final das contas, cabe perguntar se a teologia da razão não varreu da religião aquilo que de fato seria essencial para sua dinâmica específica, e se o Deus que tão bem se adequa ao projeto hegeliano não é fatalmente distinto ou contraposto ao Deus vivido pelo homo religiosus.

As reações de pensadores cristãos à definição hegeliana de cristianismo:

As acusações de ateísmo e panteísmo que pairavam sobre Hegel já desde a Fenomenologia do Espírito não amainaram com a publicação póstuma das PFR, e embora ele talvez não desejasse divulgar o livro é possível supor que com as repetidas apresentações da filosofia da religião em suas aulas ele pretendia em parte desfazer o mal estar causado pelas acusações de ateísmo. Apesar de todo o seu esforço e da posição de destaque do Cristianismo em um sistema histórico da religião, no entanto, muitos opositores e insatisfeitos insistiam que esta não se tratava de nada mais que outra exposição de seu ateísmo ou panteísmo crasso (JAESCHKE, 2016, 432; 467), gerando uma situação ambígua, já que outros grupos também viriam a considerá-lo um pensador conservador e religioso ortodoxo (JAESCHKE, 2016, 433).

Nisso os problemas geminados da imortalidade da alma e da ressurreição de Cristo escoram a crítica contra Hegel. Teria ele sido mais consequente com o sistema do que com a doutrina cristã? ${ }^{10}$ Se a resposta é positiva, ao menos se torna muito menos séria a acusação de eleger de modo parcial e enviesado o cristianismo como modelo inconteste da dialética religiosa.

A questão da imortalidade é central para a compreensão hegeliana de Deus, pois o Deus revelado e manifestado não pode se re-revelar numa outra vida no "além”. Ele já

\footnotetext{
${ }^{10}$ Essa é exatamente a alegação de Immanuel Hermann Fichte e Christian Weisse, os quais publicaram textos imediatamente após a morte de Hegel quase como uma declaração de alforria da filosofia e apontando para o retorno ao conceito de um Deus pessoal e suas consequências (JAESCHKE, 2016, 465). Também houve, no entanto, tentativas de defesa ou reformulação do sistema de Hegel para acomodar a ideia de imortalidade. A vasta bibliografia produzida nas décadas de 1830 a 1860 sobre o assunto mostra a forte repercussão da posição de Hegel contra a ideia de imortalidade da personalidade humana.
} 
está revelado, e propriamente, como o infinito, geral e concreto que se expressa na diferença e no contraste entre finitos.

Assim, não se deve imaginar a imortalidade da alma como algo que ingressa tardiamente na realidade; ela é qualidade presente. O Espírito é eterno, e, por isso, já presente; o Espírito em sua liberdade não está no círculo das limitações. Para ele, enquanto pensante, puro sapiente, o que se dá é a generalidade; esta é a eternidade, a qual não consiste em mera duração, como duram as montanhas, mas sim no saber. (HEGEL, 1970, XVII, 261)

Ora, cada indivíduo já é desde sempre tão divino e tão imortal quanto se possa ser, na medida em que sua essência é a expressão particular do todo. A revelação da divindade e da imortalidade do homem não é, portanto, a sua continuidade enquanto particular, mas a sua conscientização de seu ser desde sempre universal e infinito. Para Hegel, portanto, prolongar a vida finita e particular num mundo dos espíritos equivaleria a retrogradar para o estágio inconsciente do Espírito, negando a manifestação positiva de Jesus Cristo e a manifestação onipresente e eterna alcançada pela filosofia.

Já Immanuel Fichte criticara o Deus de Hegel como uma abstração incapaz de prover sentido à vida ou fortalecer o homem nos desafios morais e existenciais, defendendo um retorno e maior valorização da filosofia de seu pai (FICHTE, 1869, Bd. I, p. 17-18, 37) e, mais ainda, a filosofia positiva do último Schelling. "Deus mesmo é quem nos garante não se tratar de uma mera "razão geral abstrata", mero Espírito Absoluto", e sim de um ser pessoal, sumo bem, amor abundante de graça auxiliadora, pois ele se revela na vida ético-religiosa do homem (isto é, de toda a humanidade e sua história) (FICHTE, 1869, Bd. I, p. 281). Só na possibilidade de interpretar toda a história mundial, natural e humana, como desdobramento da vontade de Deus é que enxergamos a coerência moral-existencial da ordem do mundo, que de outra maneira continua a poder ser confundido com um mecanismo de relógio. Este “dedo de Deus" (FICHTE, 1869, Bd. II, p. 107) impulsionando o mundo precisa ser perceptível tanto moral quanto intelectualmente, na finalidade dos acontecimentos como na perfeição de seus processos. 
A isso Fichte acrescenta a absoluta necessidade da imortalidade da alma, sem a qual o cristianismo da pura abstração hegeliano abdica, na prática, da extensão real das promessas da religião e as expectativas do senso moral humano. No entender do Fichte filho, Hegel ignorou com excessiva soberba a naturalidade da religião, sequiosa de vida, amor, consolo para o sofrimento pessoal, e outros traços que fazem dela um atestado empírico de demandas individuais, para privilegiar, ao invés disso, somente a parte dela que falasse do geral e do infinito. Ora, a ligação entre a ideia da imortalidade e a vida moral pode - ao menos Hegel deveria ter incluído a possibilidade - não ser uma projeção defeituosa da razão sobre a verdadeira essência do homem, mas fruto de um senso divinitatis, o que faria da generalidade dessa crença um indício empírico da constituição psíquica humana ao invés de uma ideia especulativa. Tal é a posição de Lessing na Educação do gênero humano (LESSING, 1987, §42-44, §58, §60, §72), e Immanuel Fichte parece resgatá-la de preferência a aceitar as de Kant ou Hegel.

Mas Immanuel Fichte permanece dividido entre Hegel e os dois outros grandes idealistas, e também vê o cristianismo como expressão histórica positiva de um Deus que é espírito. Sua divergência com Hegel é em grande parte teológica, isto é, aponta para a exegese do que o cristianismo quer enfatizar mais do que para algum erro filosófico fundamental de Hegel.

Foi o cristianismo que pela primeira vez elevou a ideia de imortalidade à sua mais alta dignidade e pureza de conteúdo; de um lado, porque ele concebe na forma mais profunda o conceito de espírito pessoal enquanto "imagem e semelhança de Deus" e "templo do Espírito Santo", fundando, com isso, uma nova era na história, a partir da qual o homem não seria mais totalmente suplantado por algo mais alto, já que este princípio da personalidade evoluiria sempre em formas culturais futuras, enriquecendo-se; de outro lado, porque o cristianismo traz a crença na imortalidade para uma conexão inquebrável com as ideias éticas supremas. Por isso, esse seria o caráter diferenciado da nova etapa histórica universal e das novas religiões (FICHTE, 1869, Bd. II, p. 244).

\section{Conclusão:}


Como vimos, o projeto das Preleções sobre Filosofia da Religião não apenas introduz mais seriamente o conceito de religião e seu lugar na dinâmica do Absoluto, algo que foi antecipado de diversas maneiras ao longo da obra pretérita de Hegel; ele também dá à religião um papel central, um status de quintessência da cultura em suas tentativas de expressar o Espírito. Contudo, ao passo que Hegel compatibiliza de modo ímpar elementos da teologia trinitária e das noções de pessoa divina com a forma processual de sua filosofia, ele deixa, estranhamente, de fora da equação elementos igualmente capitais da fé e da filosofia cristã, como a ideia de imortalidade da alma e - o que até certo ponto é uma consequência e confirmação daquela - a ressurreição de Cristo. Tal exclusão vem a sugerir que Hegel deve ter desenvolvido um apreço muito especial por sua própria cosmovisão em detrimento do que aprendera no seminário de Tübingen, ou que ele interpretou parte do movimento modernizador como uma demanda por abandono dessas ideias.

Independentemente de quais fossem as motivações últimas de Hegel, no entanto, era de se esperar que seu esforço em "preservar" o cristianismo e a ideia geral de religião fosse recebido com desdém justamente pelos grupos que se entendiam como mais ligados a estas concepções de mundo e de vida. E diversos pensadores (a exemplo de Immanuel H. Fichte) se sentiram no dever de confrontar as influências negativas das Preleções sobre Filosofia da Religião sobre a religiosidade cristã.

Essa controvérsia nos ajuda a visualizar que a concepção cristã de Deus se associa sobremaneira à noção de um criador de individualidades mais bem plantadas no solo do ser, e que isso acarreta numa defesa ostensiva da imortalidade do espírito, o que deixa no ar a pergunta sobre o quão cristão é realmente o Deus de Hegel. Por outro lado, como apenas o status do espírito individual é diminuído, cabe também concluir que, cristão ou não, o Espírito Absoluto é Deus. 


\section{REFERÊNCIAS}

BECKERS, Hubert. Über C. F. Goschel's Versuch eines Erweises der personlichen Unsterblichkeit vom Standpunkte der Hegel 'schen Lehre aus. Mit einem Anhang uber die Anwendung der Hegel'schen Methode auf die Wissenschaft der Metaphysik. Hamburg: 1836.

COOPER, John. Panentheism. The Other God of the Philosophers. Michigan: Baker Academic, 2006.

DE NYS, Martin. Hegel and Theology. London: Continuum, 2009.

DIERKEN, Jörg. Selbstbewusstsein individueller Freiheit. Tübingen: Mohr Siebeck, 2005.

EBERT, Klaus (Hrsg.). Protestantische Mystik. Von Martin Luther bis Friedrich D. Schleiermacher. Weinheim: Deutsche Studien, 1996.

FICHTE, Immanuel H. Vermischte Schriften. Leipzig: Brockhaus, 1869.

HALFWASSEN, Jens. Hegel und der spätantike Neuplatonismus. Untersuchung zur Metaphysik des Einen und des Nous in Hegels spekulativer und geschichtlicher Deutung. Hamburg: Felix Meiner Verlag, 2005.

HEGEL, G.W.F. Hegel: Werke in 20 Bänden. Suhrkamp Verlag, 1970.

HENRICH, Dieter. Between Kant and Hegel. Cambridge: Harvard University Press, 2003.

HENRICH, Dieter. Der Ontologische Gottesbeweis: Sein Problem und seine Geschichte in der Neuzeit. Tübingen: Mohr \& Siebeck, 1960.

HENRICH, Dieter. Hegel im Kontext. Frankfurt am Main: Suhrkamp, 1967.

HODGSON, Peter. Hegel and Christian Theology. Oxford: Oxford University Press, 2005.

HÖSLE, Vittorio. God as Reason. Essays in Philosophical Theology. Notre Dame: University of Notre Dame, 2013.

JAESCHKE, Walter. Hegel Handbuch: Leben, Werk, Schule. Krugzell: Metzler Verlag, 2016. 
JAESCHKE, Walter. The History of Religion and the Absolute Religion. In: WALKER, John (ed.). Thought and Faith in the Philosophy of Hegel. Dordrecht: Springer, 1997.

KOLB, David (Ed.). New Perspectives on Hegel's Philosophy of Religion. Albany: SUNY, 1992.

LESSING, Gotthold Ephraim. Lessing Gesammelte Werke. Leipzig: Tempel Verlag,

O’REGAN, Cyril. Hegelian Philosophy of Religion and Eckhartian Mysticism. In:

HODGSON, Peter. Hegel and Christian Theology. Oxford: Oxford University Press, 2005.

MEIST, Kurt R. "Absolute" and "Consummate" Religion. In: WALKER, John (ed.). Thought and Faith in the Philosophy of Hegel. Dordrecht: Springer, 1997.

PLANTINGA, Alvin; TOOLEY, Michael. Conhecimento de Deus. São Paulo: Vida Nova, 2014.

SCHLÖSSER, Ulrich. Hegels Begriff des Geistes zwischen Theorie der Interpersonalität und Philosophie der Religion. In: HERMANNI, Friedrich;

NONNENMACHER, Burkhard; SCHICK, Friedrike (Hrsg.). Religion und Religionen im Deutschen Idealismus. Collegium Metaphysicum 13. Tübingen: Mohr-Siebeck, 2015.

VINCO, Roberto. Philosophie ist Gottesdienst. In: HERMANNI, Friedrich; NONNENMACHER, Burkhard; SCHICK, Friedrike (Hrsg.). Religion und Religionen im Deutschen Idealismus. Collegium Metaphysicum 13. Tübingen: Mohr-Siebeck, 2015.

WILLIAMS, Robert. Hegel on the Proofs and the Personhood of God. Studies in Hegel's Logic and Philosophy of Religion. Oxford: Oxford University Press, 2017. 